\title{
Phosphorylation of parathyroid secretory protein
}

\author{
(calcium/regulation/hormone/protein kinase)
}

\author{
Giruja Bhargava*†, John. Russell*, and Louis M. Sherwood*† \\ Departments of *Medicine and †Biochemistry, Albert Einstein College of Medicine, 1300 Morris Park Avenue, Bronx, New York 10461
}

Communicated by Matthew Scharf, November 5, 1982

\begin{abstract}
The phosphorylation of proteins released into the medium of bovine parathyroid gland slices or isolated cells incubated with ${ }^{32} \mathrm{P}_{\mathrm{i}}$ has been investigated. The primary protein phosphorylated had $a M_{\mathrm{r}}$ of 68,000 and coeluted with newly synthesized parathyroid secretory protein (PSP) on Bio-Gel chromatography and on polyacrylamide gel electrophoresis. Isoelectric focusing of double-labeled samples $\left(\left[{ }^{35} \mathrm{~S}\right]\right.$ methionine and $\left.{ }^{32} \mathrm{P}_{i}\right)$ revealed comigration of the two radioactive markers at a pH of 4.6, which was similar to that of purified PSP. Phosphorylation of the $M_{\mathbf{r}} \mathbf{6 8 , 0 0 0}$. protein was also demonstrated in cell homogenates incubated with $\left[\gamma_{-}{ }^{32} \mathrm{P}\right] \mathrm{ATP}$; the $M_{\mathrm{r}} 68,000$ protein was the predominant labeled protein. Increasing quantities of calcium, with and without added EGTA, caused a progressive decrease in phosphorylation of the protein. These studies demonstrate that PSP is readily phosphorylated in parathyroid cells, that the degree of phosphorylation is inversely proportional to calcium concentration, and that PSP is the major phosphorylated protein released from the gland. The relationship of phosphorylation to the potential physiologic importance of PSP remains to be determined.
\end{abstract}

Parathyroid secretory protein (PSP) is a high molecular weight glycoprotein of unknown physiologic function that is secreted by the parathyroid gland (1-4) and has recently been purified from bovine parathyroid glands $(5,6)$. Like parathyroid hormone (PTH), its secretion is inversely proportional to extracellular calcium concentration (7-9), with PSP and PTH accounting for $50 \%$ and $20 \%$ of the newly. synthesized protein released by the gland (1). The mechanism by which calcium regulates the secretion of these two proteins is under active investigation. A general mechanism for regulation of protein phosphorylation by calcium has been suggested in other tissues and appears to involve calmodulin-dependent protein kinase activity that catalyzes the phosphorylation of endogenous substrates $(10,11)$.

In the present study, we examined the phosphorylation of endogenous proteins in the parathyroid gland. We report here on the phosphorylation of an endogenous protein of $M_{\mathrm{r}} 68,000$ that is actively released by the gland and is indistinguishable from PSP.

\section{MATERIALS AND METHODS}

Materials. Carrier-free ${ }^{32} \mathrm{P}_{\mathrm{i}}$ or $\left[\gamma_{-}{ }^{32} \mathrm{P}\right] \mathrm{ATP}(10 \mathrm{Ci} / \mathrm{mmol} ; 1$ $\left.\mathrm{Ci}=3.7 \times 10^{10} \mathrm{~Bq}\right)$ and $\mathrm{L}-\left[{ }^{35} \mathrm{~S}\right]$ methionine $(940 \mathrm{Ci} / \mathrm{mmol})$ were obtained from Amersham. Ampholytes (pH 3.5-7.0) were obtained from LKB. All chemicals used in column chromatography and gel electrophoresis including $M_{\mathrm{r}}$ standards were from Bio-Rad.

Methods. Fresh bovine parathyroid glands were obtained from the slaughterhouse and kept on ice. They were trimmed of fat and then slices were prepared with a Stadie-Riggs tissue slicer. The slices were incubated with ${ }^{32} \mathrm{P}_{\mathrm{i}} \cdot(100 \mu \mathrm{Ci} / \mathrm{ml})$ with

The publication costs of this article were defrayed in part by page charge payment. This article must therefore be hereby marked "advertisement" in accordance with $18 \mathrm{U}$. S. C. $\$ 1734$ solely to indicate this fact. and without $\left.{ }^{35} \mathrm{~S}\right]$ methionine $(10 \mu \mathrm{Ci} / \mathrm{ml})$ in a shaking water bath for $2-4 \mathrm{hr}$ at $37^{\circ} \mathrm{C}$. in phosphate-free Krebs-Ringer bicarbonate buffer (KRB buffer; $120 \mathrm{mM} \mathrm{NaCl} / 4.75 \mathrm{mM} \mathrm{KCl} / 1.2$ $\mathrm{mM} \mathrm{MgCl} / 2 / 0.5$ or $2.5 \mathrm{mM} \mathrm{CaCl} / 25 \mathrm{mM} \mathrm{NaHCO}$, pH 7.4 , containing $2 \mathrm{mg}$ of glucose per $\mathrm{ml}$ ) in an atmosphere of $95 \% \mathrm{O}_{2}$ / $5 \% \mathrm{CO}_{2}$. At the end of the incubation period, the medium was separated from tissue by centrifugation at $650 \times \mathrm{g}$ for $10 \mathrm{~min}$ in a refrigerated centrifuge. Medium was then centrifuged at $8,500 \times g$ for $20 \mathrm{~min}$ and used for further studies. Isolated cells were prepared by the method of Brown et al. (12) and were incubated with ${ }^{32} \mathrm{P}_{\mathrm{i}}$ in phosphate-free KRB buffer. Cells and media were then processed for $\mathrm{NaDodSO}_{4} /$ polyacrylamide gel electrophoresis or column chromatography on Bio-Gel A-1.5m $(1.2 \times 75 \mathrm{~cm})$ in $0.15 \mathrm{M}$ ammonium bicarbonate $\mathrm{pH} 7.8$ buffer. After column chromatography, the radioactive peak fractions were pooled, lyophilized, and analyzed further.

For polyacrylamide gel electrophoresis, the proteins in the medium were precipitated by addition of an equal volume of $20 \%$ trichloroacetic acid at $4^{\circ} \mathrm{C}$. The medium was then washed with $10 \%$ and $5 \%$ trichloroacetic acid; extracted with ether, and dissolved in $\mathrm{NaDodSO}_{4}$ sample buffer [ $125 \mathrm{mM}$ Tris $\cdot \mathrm{HCl}, \mathrm{pH}$ $6.8 / 1 \% \mathrm{NaDodSO}_{4} / 5 \%$ (vol/vol) 2-mercaptoethanol/10\% (vol/ vol) glycerol]. $\mathrm{NaDodSO}_{4} /$ polyacrylamide gel electrophoresis was performed on $10 \%$ acrylamide slab gels with the discontinuous buffer system described by Maizel (13). Gel scanning was performed with a densitometer (E. C. Apparatus, St. Petersburg, FL).

\section{RESULTS}

When parathyroid gland slices or isolated cells were incubated for $120 \mathrm{~min}$ with ${ }^{32} \mathrm{P}_{\mathrm{i}}$ and the medium proteins were precipitated and separated on polyacrylamide gel electrophoresis followed by radioautography, the dominant protein was a 68,000 dalton ${ }^{32} \mathrm{P}$-labeled protein which eluted in a position corresponding to that of highly purified bovine PSP (Fig. 1). Gel filtration (Bio-Gel A-1.5m) of ${ }^{32} \mathrm{P}$-labeled medium proteins revealed a peak of radioactivity in the position where marker ${ }^{125} \mathrm{I}$ labeled PSP ( ${ }^{125} \mathrm{I}$-PSP) eluted (Fig. 2). When both ${ }^{32} \mathrm{P}_{\mathrm{i}}$ and $\left.{ }^{35} \mathrm{~S}\right]$ methionine were incubated with parathyroid slices for $4 \mathrm{hr}$ and the medium was analyzed on the same column, $\left[{ }^{35} \mathrm{~S}\right]$ methionine appeared in both the PSP and PTH peaks (5), whereas only PSP contained ${ }^{32} \mathrm{P}$. The elution position of ${ }^{125} \mathrm{I}-$ PSP had previously been determined by its passage over the same column (5). When the column fractions on Fig. 2 were analyzed by radioimmunoassay for bovine PSP (5), immunoreactivity appeared only in the dominant peak at tube 45 which was phosphorylated. The higher molecular weight peak observed in Fig. 2 and on gel electrophoresis (Fig. 1) was not studied further.

When the peak of ${ }^{32} \mathrm{P}$-labeled protein from the Bio-Gel column was analyzed by $\mathrm{NaDodSO}_{4}$ /polyacrylamide gel electro-

Abbreviations: PSP, parathyroid secretory protein; PTH, parathyroid hormone. 


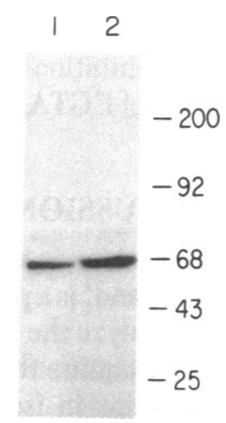

FTG. 1. Phosphorylation of $M_{\mathrm{r}} 68,000$ protein. Tissue slices or isolated bovine parathyroid cells $\left(1.0 \times 10^{6}\right)$ were incubated with ${ }^{32} \mathrm{P}_{\mathrm{i}}(100$ $\mu \mathrm{Ci} / \mathrm{ml}$ ) in phosphate-free KRB buffer for $120 \mathrm{~min}$. Trichloroacetic acid-precipitated proteins from the medium were subjected to electrophoresis on $10 \%$ acrylamide $/ 0.26 \%$ bisacrylamide separating gel. The stacking gel was $3 \%$ acrylamide $/ 0.35 \%$ bisacrylamide. After electrophoresis, the gels were stained, dried, and exposed to Kodak X-AR film. Lanes: 1 , medium from incubation of slices; 2 , medium from incubation of cells. $M_{\mathrm{r}}$ is shown $\times 10^{-3}$.

phoresis, a single 68,000-dalton band that comigrated with authentic purified bovine PSP was observed. When the phosphorylated protein was analyzed by isoelectrofocusing, the ${ }^{32} \mathrm{P}$ labeled peak was identified at $\mathrm{pH}$ 4.6. When double-labeled protein $\left({ }^{35} \mathrm{~S}\right]$ methionine and $\left.{ }^{32} \mathrm{P}\right)$ was analyzed, the two radio labels comigrated (Fig. 3).

The effect of calcium on the amount of radiolabeled $M_{\mathrm{r}}$ 68,000 protein secreted into the medium was also studied. Tissue slices were incubated in phosphate-free KRB buffer containing low $(0.5 \mathrm{mM})$ and high $(2.5 \mathrm{mM})$ concentrations of calcium. The amount of radioactivity $\left({ }^{35} S\right.$ and $\left.{ }^{32} \mathrm{P}\right)$ in the $M_{\mathrm{r}} 68,000$ protein was quantitated by Bio-Gel column chromatography and $\mathrm{NaDodSO}_{4}$ /polyacrylamide gel analysis. At $2.5 \mathrm{mM}$ calcium, there was a significant reduction in both ${ }^{32} \mathrm{P}$ and $\left[{ }^{35} \mathrm{~S}\right]-$ methionine recovered in the secreted protein $(55-65 \%$ less than at $0.5 \mathrm{mM}$ calcium). $\mathrm{NaDodSO}_{4} /$ polyacrylamide gel electro-

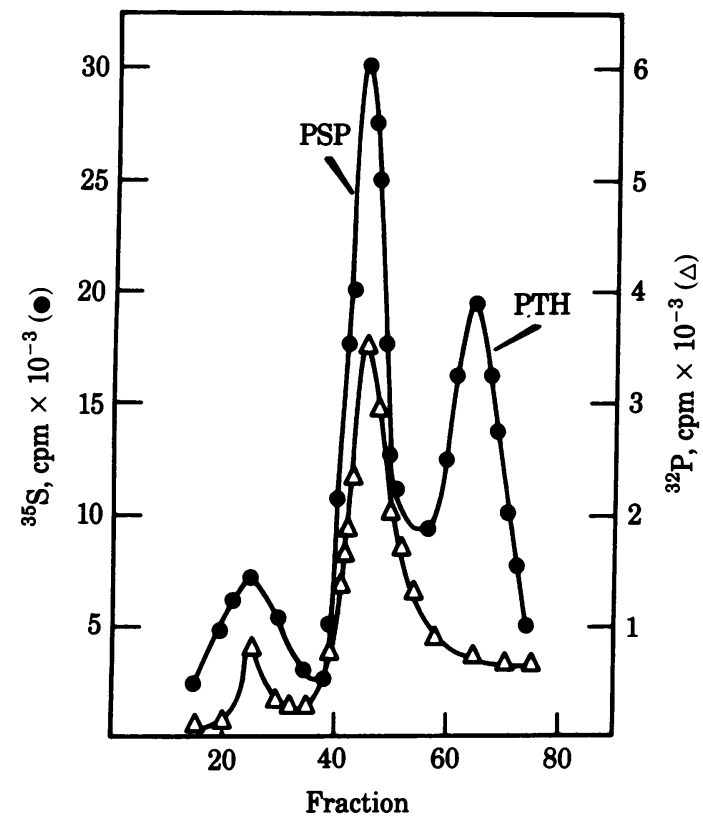

Fig. 2. Gel filtration of medium proteins on Bio-Gel A-1.5m. Parathyroid gland slices were incubated with ${ }^{32} \mathrm{P}_{\mathrm{i}}(1 \mathrm{mCi})$ and $\left.{ }^{35} \mathrm{~S}\right]$ methionine $(0.1 \mathrm{mCi})$ for $4 \mathrm{hr}$ in phosphate-free $\mathrm{KRB}$ buffer. Chromatography of lyophilized medium was performed on a $1.2 \times 75 \mathrm{~cm}$ column; $1.0-\mathrm{ml}$ fractions were assayed for radioactivity.

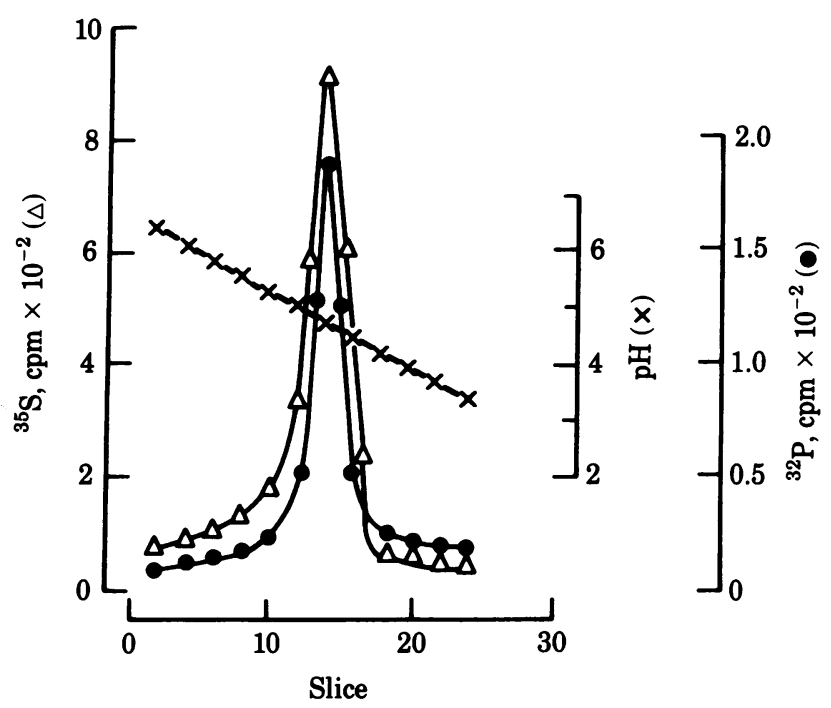

Fig. 3. Isoelectric focusing of $M_{\mathrm{r}} 68,000$ protein labeled with ${ }^{32} \mathrm{P}$ and $\left[{ }^{35}\right.$ S $]$ methionine. The peak of radioactively labeled protein (fraction 45 in Fig. 2) was analyzed on $4 \%$ polyacrylamide gels and on an isoelectric focusing gradient from $\mathrm{pH} 3.5$ to 7.0.

phoresis of ${ }^{32} \mathrm{P}$ - and ${ }^{35} \mathrm{~S}$-labeled $M_{\mathrm{r}} 68,000$ protein at 0.5 and 2.5 $\mathrm{mM}$ calcium is shown in Fig. 4.

The ratio of ${ }^{32} \mathrm{P}$ to ${ }^{35} \mathrm{~S}$ in the $M_{\mathrm{r}} 68,000$ protein in the medium at $0.5 \mathrm{mM} \mathrm{Ca}$ appeared to be similar to that at $2.5 \mathrm{mM} \mathrm{Ca}$, which may indicate that the decrease in ${ }^{32} \mathrm{P}$ is primarily due to decreased secretion of newly synthesized PSP. Separate experiments have shown a 65-75\% decrease in total secreted PSP at high $\mathrm{Ca}^{2+}(9)$.

Incubation of lysate prepared from isolated parathyroid cells with $\left[\gamma_{-}{ }^{32} \mathrm{P}\right]$ ATP resulted in incorporation of ${ }^{32} \mathrm{P}$ into various proteins, but the most heavily labeled one observed was at 68,000 daltons (Fig. 5). The intensity of the $M_{\mathrm{r}} 68,000$ band decreased with increasing calcium concentration from 0 to 3.0 $\mathrm{mM}$. In separate incubations, the concentration of calcium was

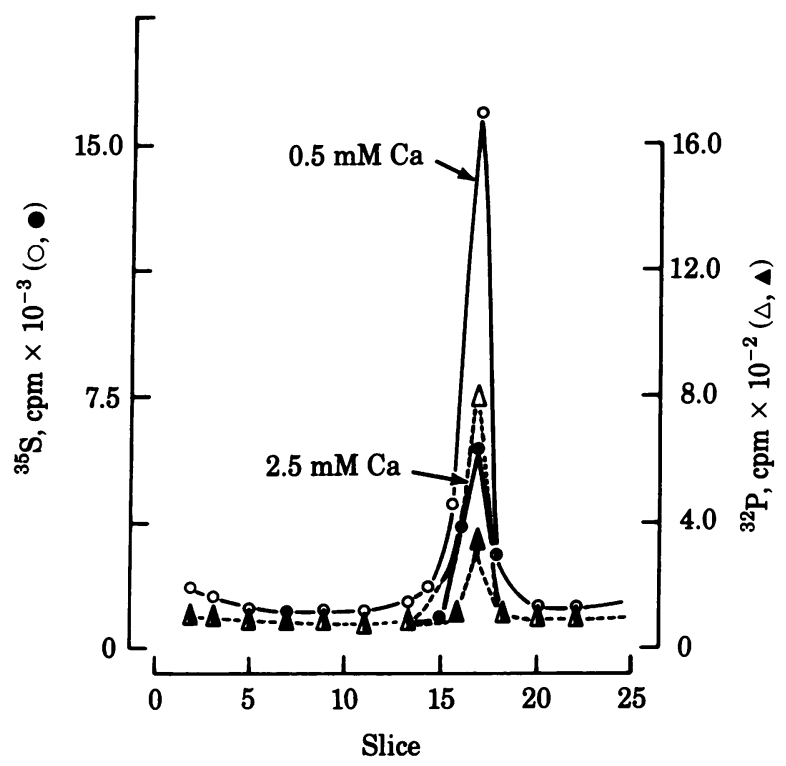

Fig. 4. Effect of calcium on the secretion of double-labeled $M_{\mathrm{r}}$ 68,000 protein. Tissue slices were incubated for $4 \mathrm{hr}$ at $37^{\circ} \mathrm{C}$ in phosphate-free $\mathrm{KRB}$ buffer containing $0.5 \mathrm{mM}(0, \Delta)$ or $2.5 \mathrm{mM}(\bullet, \Delta) \mathrm{CaCl}_{2}$, ${ }_{l}-\left[{ }^{35} \mathrm{~S}\right]$ methionine at $10 \mu \mathrm{Ci} / \mathrm{ml}$, and ${ }^{32} \mathrm{P}_{\mathrm{i}}$ at $100 \mu \mathrm{Ci} / \mathrm{ml}$. The medium was analyzed by $\mathrm{NaDodSO}_{4} /$ polyacrylamide gel electrophoresis. 


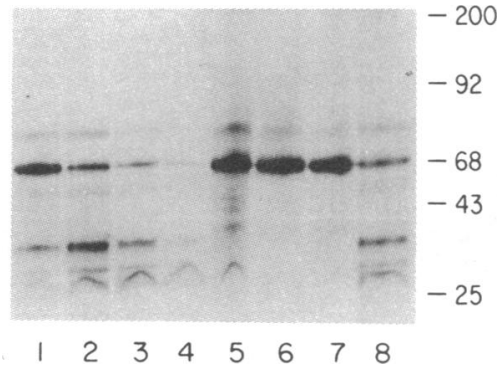

Fig. 5. Regulation of phosphorylation of $M_{\mathrm{r}} 68,000$ protein by calcium. Isolated bovine parathyroid cells were washed with phosphatefree $\mathrm{KRB}\left(0.5 \mathrm{mM} \mathrm{Ca}{ }^{2+}\right.$ ), and homogenized in $20 \mathrm{mM}$ Hepes, $\mathrm{pH} \mathrm{7.0/}$ $10 \mathrm{mM} \mathrm{MgCl} / 2 / 0.1 \mathrm{mM}$ dithiothreitol. The homogenate was incubated with $5 \mu \mathrm{M}\left[\gamma^{32} \mathrm{P}\right] \mathrm{ATP}(10 \mathrm{Ci} / \mathrm{mmol})$ in a final volume of $0.1 \mathrm{ml}$ at $30^{\circ} \mathrm{C}$ for 2 min at different concentrations of calcium and EGTA. The reaction was terminated by addition of $50 \mu \mathrm{l}$ of sample buffer, and the samples were kept in a boiling water bath for $5 \mathrm{~min}$. Polyacrylamide gel electrophoresis was performed on 50- $\mu$ l aliquots of reaction mixture. Dried gel was exposed to X-Omat AR film. In lanes 1, 2, 3, and 4 , the concentration of calcium was $0,0.5,1.0$, and $3.0 \mathrm{mM}$, respectively. In lanes 5, 6, 7, and 8, 2.0 mM EGTA was incubated with homogenate in the presence of $0,0.5,1.0$, and $3.0 \mathrm{mM}$ calcium, respectively.

further decreased by adding $2.0 \mathrm{mM}$ EGTA. In the absence of added calcium, the addition of $2 \mathrm{mM}$ EGTA resulted in a significant increase in phosphorylation. Addition of increasing concentrations of calcium (calculated free $\mathrm{Ca}^{2+}$ concentrations at $0.5,1.0$, and $3.0 \mathrm{mM}$ calcium were $0.1 \mu \mathrm{M}, 0.28 \mu \mathrm{M}$, and 1.0 $\mathrm{mM}$, respectively, on the basis of stability constant $K=4.4$ $\left.\times 10^{6} \mathrm{M}^{-1}\right)$ in the presence of EGTA resulted in a decrease in phosphorylation of PSP. The densitometric scans of the gels in
Fig. 5 are shown in Fig. 6. At increasing calcium concentrations in the absence of EGTA, the inhibition was $65 \%, 77 \%$, and $90 \%$, respectively. In the presence of EGTA, the inhibition was $24 \%$, $29 \%$, and $85 \%$, respectively.

\section{DISCUSSION}

The present report provides evidence that PSP, a major protein secreted by the parathyroid gland, is a phosphoprotein. In these studies, we have chosen to analyze the medium for phosphorylated proteins rather than to examine the entire profile of phosphorylated cytoplasmic proteins in isolated cells. In the medium, PSP and PTH are the major secretory proteins, and we have been able to document that PSP is phosphorylated in the cell prior to its release. We have also isolated the phosphorylated protein by passage through Bio-Gel columns. The protein has a $\mathrm{pI}$ value of $\approx 4.6$, which is similar to that of highly purified homogeneous preparations of bovine PSP (6). A pI value in the range 4.9-5.2 was reported for PSP made in in vitro translation systems as well as PSP derived from bovine tissue (14). The phosphorylated protein thus behaved identically to purified PSP on isoelectric focusing, column chromatography, and polyacrylamide gel electrophoresis.

It will be necessary to examine the kinetics of ${ }^{32} \mathrm{P}$ labeling of this protein over longer periods of time and to determine if an increase in the ratio of ${ }^{32} \mathrm{P}$ to $\left[{ }^{35} \mathrm{~S}\right]$ methionine is achieved over time. We have routinely used 2- and 4-hr incubations because secretion of PSP increases linearly with time up to $4 \mathrm{hr}$ (7-9), and regulation of secretion by calcium has been investigated at these time periods.

PSP is associated with PTH in the secretory granule $(15,16)$ and could play an important role in secretion of the hormone. Phosphorylation of soluble granule proteins and secretory gran-
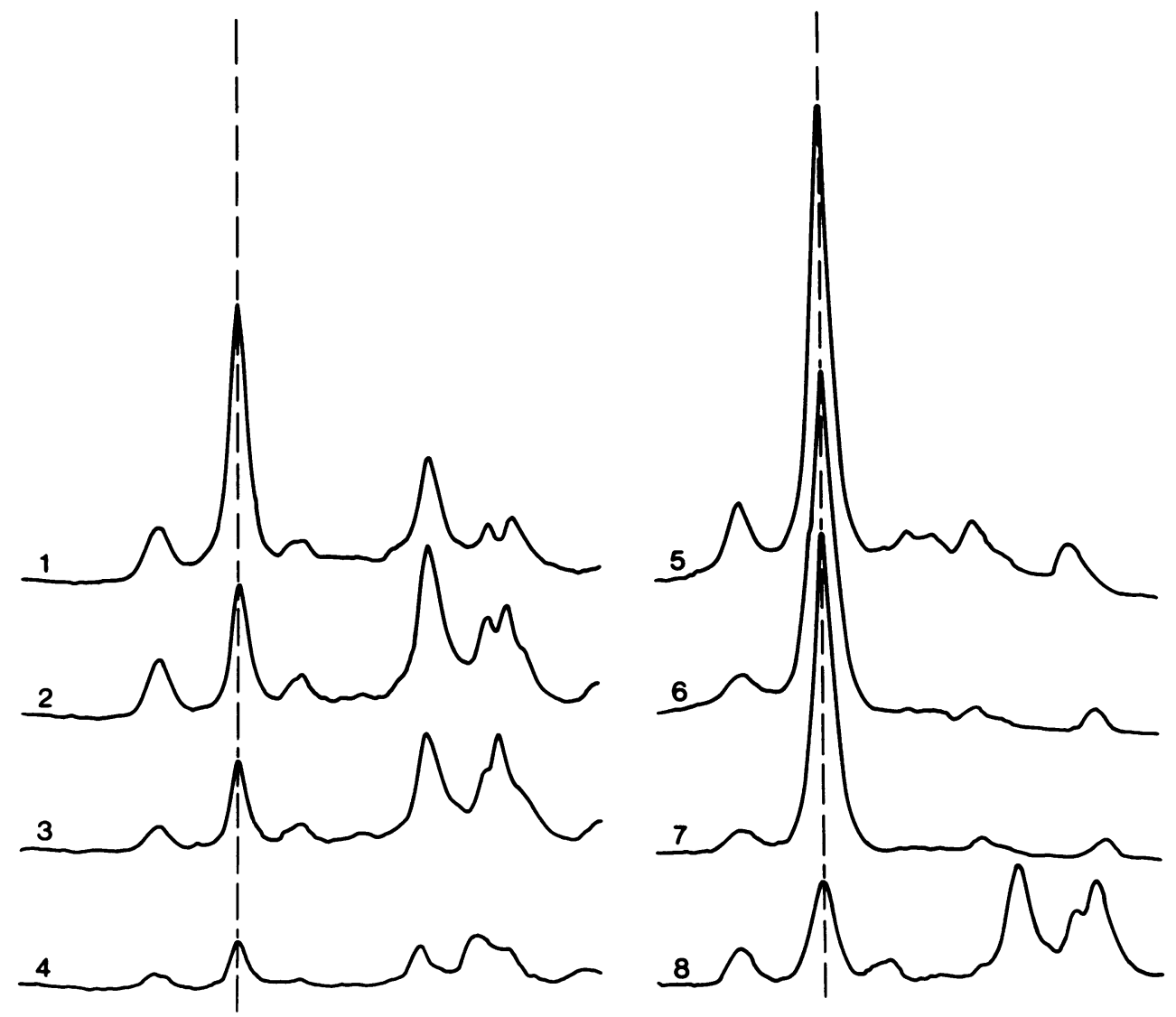

FIG. 6. Densitometric scans of gels in Fig. 5. Dashed line marks the peaks representing labeled PSP. 
ule membranes in the parathyroid cell may be important in exocytosis, but this has not been investigated in the parathyroid previously. Examples of secreted proteins that are phosphorylated include casein (17), ovalbumin (18), myosin light chain (19), and a $M_{\mathrm{r}} 68,000$ protein from peritoneal mast cells (20). Phosphorylation of pro-ACTH/endorphin-derived peptides has also recently been described (21).

It is also important to study calcium and cAMP regulation of phosphorylation. In the in vitro system used, we have shown that phosphorylation of this protein is maximal in the presence of EGTA and in the absence of added calcium. It is tempting to speculate that the inhibitory effect of calcium on PTH secretion from parathyroid cells is mediated via phosphorylation/ dephosphorylation mechanisms involving PSP. A possible mechanism for increased phosphorylation of this protein may include an increase in the local concentration of cAMP or cGMP brought about by inhibition of calmodulin-dependent phosphodiesterase activity through changes in cytosol calcium concentration $(22,23)$. Addition of EGTA to bovine parathyroid cell sonicates inhibits both cAMP and cGMP phosphodiesterase activities $(24,25)$.

Studies implicating calmodulin and calcium-dependent phosphorylation of endogenous proteins in several secretory systems have recently been reported (26-28). In all such instances, stimulation of protein phosphorylation was observed. Unlike other systems, however, PTH and PSP release is inhibited, not stimulated, by increased extracellular calcium concentration. Further studies involving intact cell systems will be needed to determine whether phosphorylation of PSP mediates the effects of calcium on PTH secretion (29).

We thank Ms. Luciana Lesch for excellent assistance in the preparation of this manuscript. This work was supported in part by Grant AM28556 from the Public Health Service.

1. Kemper, B., Habener, J. F., Rich, A. \& Potts, J. T., Jr. (1974) Science 184, 167-169.

2. Au, W. Y. W., Poland, A. P., Stern, P. H. \& Raisz, L. G. (1970) J. Clin. Invest. 49, 1639-1646.

3. Sherwood, L. M., Rodman, J. S. \& Lundberg, W. B. (1970) Proc. Natl. Acad. Sci. USA 67, 1631-1638.

4. Licata, A. A., Au, W. Y. W. \& Raisz, L. G. (1972) Biochim. Biophys. Acta 261, 143-147.

5. Takatsuki, K., Schneider, A. B., Shin, K. Y. \& Sherwood, L. M. (1981) J. Biol Chem. 256, 2342-2345.
6. Cohn, D. V., Morrissey, J. J., Hamilton, J. W., Shofstall, R. E., Smaron, F. L. \& Chu, L. L. H. (1981) Biochemistry 20, 41354140.

7. Habener, J. F. \& Potts, J. T., Jr. (1976) Endocrinology 98, 197202.

8. Morrissey, J. J. \& Cohn, D. V. (1978) Endocrinology 103, 20812090.

9. Sherwood, L. M., Takatsuki, K., Porat, A., Shin, K. Y. \& Jackimek, A. (1981) Clin. Res. 29, 579 (abstr.).

10. Schulman, H. \& Greengard, P. (1978) Nature (London) 271, 478479.

11. Schulman, H. \& Greengard, P. (1978) Proc. Natl. Acad. Sci. USA 75, 5432-5436.

12. Brown, E. M., Hurwitz, S. \& Aurbach, G. D. (1976) Endocrinology 99, 1582-1588.

13. Maizel, J. V., Jr. (1971) Methods Virol. 5, 179-182.

14. Majzoub, J. A., Kronenberg, H. M., Potts, J. T., Jr., Rich, A. \& Habener, J. F. (1979) J. Biol Chem. 254, 7449-7455.

15. Cohn, D. V. \& MacGregor, R. R. (1981) Endocr. Rev. 2, 1-26.

16. Ravazzola, M., Orci, L., Habener, J. F. \& Potts, J. T., Jr. (1978) Lancet ii, 371-372.

17. Pinna, L. A., Meggio, F. \& Donella-Deana, A. (1980) in Protein Phosphorylation and Bioregulation, eds. Thomas, G., Podesta, E. J. \& Gordon, J. (Karger, New York), pp. 8-16.

18. Henderson, J. Y., Moir, A. J. G., Fothergill, L. S. \& Fothergill, J. E. (1981) Eur. J. Biochem. 114, 439-450.

19. Wallace, C. W. \& Bensusan, H. B. (1980) Proc. Natl. Acad. Sci. USA 255, 1932-1937.

20. Sieghart, W., Theoharis, T. C., Alper, S. L., Douglas, W. W. \& Greengard, P. (1978) Nature (London) 275, 329-330.

21. Eipper, B. A. \& Mains, R. E. (1982) J. Biol Chem. 257, 49074915.

22. Habener, J. F., Stevens, T. D., Ravazzola, M., Orci, L. \& Potts, J. T., Jr. (1977) Endocrinology 101, 1524-1537.

23. Brown, E. M., Gardner, D. G. \& Aurbach, G. D. (1980) Endocrinology 106, 133-138.

24. Brown, E. M. (1980) Endocrinology 107, 1998-2003.

25. Willgoss, D., Jacobi, J. M., DeJersey, J., Bartley, P. C. \& Lloyd, H. M. (1980) Biochem. Biophys. Res. Commun. 94, 763-768.

26. DeLorenzo, R. J., Freedman, S. D., Yohe, W. B. \& Maurer, S. C. (1979) Proc. Nath. Acad. Sci. USA 76, 1838-1842.

27. Schubart, U. K., Ehrlichman, J. \& Fleischer, N. (1980) J. Biol. Chem. 255, 4120-4124.

28. Drust, D. S. \& Martin, T. F. J. (1982) J. Biol Chem. 257, 75667573.

29. Targovnik, J. H., Rodman, J. S. \& Sherwood, L. M. (1971) Endocrinology 88, 1477-1482. 